\title{
Perceptions of entrepreneurial ecosystems in remote islands and core regions
}

\author{
Carmen Freitas \\ Department of Management \& Economics, University of Madeira, Portugal \\ carmenf@staff.uma.pt (corresponding author) \\ Michael Kitson \\ Cambridge Judge Business School, University of Cambridge, UK \\ m.kitson@jbs.cam.ac.uk
}

\begin{abstract}
The existence of an effective entrepreneurial ecosystem is important for economic development and growth. This study considers how entrepreneurial ecosystems are perceived and operate in different locations focusing on remote islands compared to core/central regions. In particular, this study focuses on two remote island economies (the Canary Islands, in Spain, and Madeira, in Portugal), compared with Catalonia and Lisbon which are two core regions in Spain and Portugal. The evidence, based on a large-scale survey, shows that firms in remote islands perceive that they operate in a less favourable entrepreneurial ecosystem compared to firms in core regions although the findings show that there are significant variations across sectors of activity. Thus, the appropriate strategies for entrepreneurial action and for policy makers will vary depending on the characteristics of the ecosystem.
\end{abstract}

Keyword: entrepreneurial ecosystems, entrepreneurship, islands, new firm formation, regional policy, remote and core regions.

https://doi.org/10.24043/isj.44

(C) 2018 - Institute of Island Studies, University of Prince Edward Island, Canada.

\section{Introduction}

Entrepreneurship is a fundamental factor of economic and social development which helps explain regional disparities in economic growth (Audretsch \& Thurik, 2004; Wennekers \& Thurik, 1999). Regional economic and institutional conditions not only vary but will play a crucial role in the entrepreneurial process (Gartner, 1985). In particular, new firms are directly influenced by their locality, their survival being dependent on their adaptability and ability to maximize entrepreneurial efforts within a specific environmental setting (Aldrich \& Martinez, 2001; Baldacchino et al., 2008; Romanelli, 1989). Recent research has cast this process in the context of local or regional entrepreneurial ecosystems; a concept first coined by Moore (1993) which, according to Isenberg (2010, p. 43) "consists of a set of individual elements - such as leadership, culture, capital markets, and open-minded customers-that combine in complex ways" to promote the entrepreneurial activity.

This study focuses a key dimension of entrepreneurship: perceptions of the entrepreneurial ecosystem and factors and problems that encourage and constrain entrepreneurial activity (here defined as new firm formation). To highlight the importance of location, this study focuses on remote or peripheral locations compared to core or central regions. In particular, this study focuses on two remote island economies (the Canary Islands in Spain and Madeira in Portugal) which can be characterized as sub-national island jurisdictions according to Baldacchino (2006); compared with Catalonia and Lisbon which are two core regions in Spain and Portugal (Martin, 
2003) respectively. Although remote islands may be expected to have a unique and uncertain ecosystem for entrepreneurial activity, there is limited analysis of entrepreneurship in this type of region (Baldacchino \& Fairbairn, 2006; Burnett \& Danson, 2017; Danson \& Burnett, 2014; Garcia-Rodriguez et al., 2016; Lovelock et al., 2010; Yusuf, 1995). For Read (2008), one of the reasons for this gap in the literature is the low absolute volume of capital flows. This study helps to address the gap by investigating the following research questions: what do entrepreneurs perceive to be the differences in the entrepreneurial ecosystem between remote islands and core regions; and what differentiates the new firm formation process in remote islands compared with core regions? In doing so, we contribute to the study of entrepreneurship by analysing the uniqueness of the phenomenon in the specific context of island economies.

This paper is structured as follows. The next section analyses the concept of the entrepreneurial ecosystem and discusses the differences between remote and core regions to help develop the research hypotheses. The third section outlines the research methodology and the data collection process. The fourth section presents the main results of the study. The final section concludes and includes the implications for policy.

\section{Spatial differences in entrepreneurship ecosystems: theory and hypotheses}

\section{Economic and entrepreneurial activity on remote islands}

According to Sufrauj (2011, p. 20), "Size and geography contribute largely to shaping the economic structure of nations [...] smallness and remoteness are features that are likely to deter the economies of islands." Briguglio (1995) identified two important vulnerabilities of remote islands: small size; and insularity and remoteness. These vulnerabilities impact economic activity in remote islands due to:

Limited natural resource endowments leading to a high import content; limitations on import-substitution possibilities due to the small size of the domestic market; dependence on a narrow range of products and services; limited ability to influence domestic prices of exports and imports; limited ability to exploit economies of scale, mostly due to indivisibilities and limited scope for specialization; (and) limitations on domestic competition (Briguglio, 1995, pp. 1616-1617).

Therefore, the specific characteristics of the remote islands will result in a "rent-seeking economic structure, limited industrialization, a relatively large bloated public sector, and a very small private sector" (Baldacchino, 1999, p. 80) and have adverse effects on their economic growth (Read, 2004). Thus, the nature of entrepreneurial activity will be constrained by resources and conditions and, consequently, will generally be oriented to imports, trade, and consumption (Baldacchino, 2005).

\section{Entrepreneurial ecosystems}

The entrepreneurship ecosystem is an arrangement of fundamental activities and resources which determine regional entrepreneurial dynamics (Ács et al., 2015). It comprises “a set of interconnected entrepreneurial actors and organizations, institutions, and entrepreneurial processes which formally and informally coalesce to connect, mediate and govern the performance within the local entrepreneurial environment" (Mason \& Brown, 2014, p. 5). Several empirical studies have identified the factors, characteristics, and conditions perceived as fundamental to the development of entrepreneurial activity in a region (e.g. Bull \& Winter 1991; Fritsch \& Schindele, 2011). These studies identify six important domains of the entrepreneurial ecosystem: social and demographic, economic, technological, financial, infrastructural, and policy. 
Entrepreneurial ecosystems in remote and core regions: some hypotheses

Remote and core regions are at two ends of the location spectrum: the location of the former potentially leads to low economic development and growth; whereas the latter may have all the necessary resources to flourish-economically, socially, and culturally. Kaufmann and Malul (2015, p. 1345) define a core region "as a region with strong, concentrated economic activity that exhibits economies of scale and specialization." Whereas a remote region, which can be rural and/or peripheral, is at the "edge of a communication system, where they are away from the core or controlling centre of the economy" (Goodall, 1987, p. 350). Anderson (2000) emphasizes that peripheral regions are best understood as a subordinate to a core region, and are usually characterized as: separated in space from the core regions; with limited markets, income, growth, scale of production, and skilled labour, which condemns peripheral firms to remaining small; and different in cultural terms when compared to core regions. Additionally, the peripherality may also create the added barrier of limited access to information (Beer, 2004).

The notion of remoteness is a relative concept, and in the specific case of small islands this concept is magnified due to: the limited extent of labour market, a small population that might be further reduced by the emigration of skilled labour, and a small domestic market which fosters the formation of local oligopolies and monopolies (Sufrauj, 2011). These regions will also suffer from inadequate access to technology and investment capital (Baldacchino, 1999), from limited economic interactions (Sufrauj, 2011), and from limited accessibility, being in disadvantage "compared with the mainland for transport choice, travel time and costs" (Spilanis et al., 2013, p. 2016). However, the discussion of peripherality and remoteness in the small island context is not straightforward. As Grydehøj et al. (2015, p. 4) emphasize, the field of island studies needs to understand:

islands on their own terms precisely by combatting the futile provincialisations of an island rhetoric that tacitly accepts the dominance of the centre in its championing of the periphery. Only by permitting ourselves to regard islands as centres within complex networks of centrality and peripherality - rather than simply as peripheries or as mystical centres unto themselves - can we transcend the savage inequalities of how we speak about and act upon both islands and mainlands. Only then can we place islands in context and place context on islands.

Moreover, not all authors agree with the "vulnerability paradigm" surrounding small islands (e.g. Baldacchino, 2015). Baldacchino and Bertram (2009) present different development alternatives, where the specificities of island economies are not insurmountable obstacles but are characteristics that can lead to dynamic flexibility. However, a strong stream of literature argues that remote islands have deficiencies in their entrepreneurial ecosystems compared to core regions, making the former less attractive for economic activities (Spilanis et al., 2013) leading to the following hypotheses.

- Hypothesis 1: firms in core regions will perceive that they operate in a more favourable entrepreneurial ecosystem compared to firms that operate in remote islands (where 'entrepreneurial ecosystem' domains are social and demographic, economic, technological, financial, infrastructural, and policy).

Entrepreneurial opportunity is defined "as a situation in which a person can create a new means-ends framework for recombining resources that the entrepreneur believes will yield a profit" (Shane, 2003, p.18); its discovery is perceived as essential for entrepreneurship activity (Shane \& Venkataraman, 2000). In this process, the access to information is fundamental (Shane, 2000) and this is influenced by an individual's life experience, social networks, and social processes (Mason \& Harvey, 2013). Additionally, context will also be an important factor, as stressed by Welter (2011, p. 165), “context simultaneously provides individuals with entrepreneurial opportunities and sets boundaries for their actions; in other words, individuals may experience it 
as asset and liability." Given the unique characteristics of island economies discussed above, especially a limited access to information (Beer, 2004); limited resources and capacities to participate in relevant network activities; low density of research, development, and innovation; and technology and skills gap (European Union, 2017), it is hypothesised that:

- Hypothesis 2: firms in core regions will perceive it to be easier to identify a business opportunity in their sector of activity compared to firms that operate in remote islands.

\section{Importance of government policy for remote islands}

Isenberg (2011, p. 13) argues that the main function of government is to cultivate a virtuous cycle of entrepreneurship, and that the shortest path is to "directly create, enhance, cultivate, evolve-a geographically concentrated ecosystem that is conducive to entrepreneurship and its success." To achieve effective results, policy measures need to be customized and tailored to the local area (Cheng \& Li, 2011; Dubini, 1989; Frederick \& Monsen, 2009; Fritsch \& Storey, 2014). This differentiation is required because there are considerable differences in regional entrepreneurship ecosystems, and policy needs to be adapted to island specificities (Spilanis et al., 2013). In remote islands, governmental policy can influence the development of entrepreneurial activity as it can address gaps in resources and competence needs of entrepreneurial firms (Amorós et al., 2013; Levie \& Autio, 2008). Therefore, island entrepreneurs consider government support a critical factor for their success (Yusuf, 1995). It is thus hypothesised that:

- Hypothesis 3: in terms of new firm formation, the support from governmental policy will be more important for firms in remote islands compared with firms in core regions.

New firm formation process is the action undertaken by entrepreneurs to legally create an entity to explore a business opportunity. Support from government to assist new entrepreneurs includes low legal requirements to establish a business and attractive fiscal incentives.

\section{Geographic and economic constraints of remote islands}

Regions that have good access to resources, a large market size, and an encouraging entrepreneurial culture may be expected to have more dynamic entrepreneurial activity compared to regions that have geographic and economic constraints, defined as: 1) high transportation costs, 2) small regional market, 3) low economic diversity, 4) high geographic distance from customers, and 5) high geographic distance from suppliers. Thus, it can be hypothesized that:

- Hypothesis 4: when establishing new firms, entrepreneurs in remote islands will place more emphasis on problems linked to geographic and economic constraints compared to entrepreneurs establishing firms in core regions.

\section{Data and methods}

This study considers the entrepreneurial ecosystems in four regions in two countries: Spain (Canary Islands and Catalonia) and Portugal (Madeira and Lisbon). Additionally, three different sectors of activity were analysed: medical and dental instruments and supplies (manufacturing); travel agencies, tour operator reservation services and related activities and amusement and recreation activities (tourism); legal accounting, book-keeping, and auditing activities and tax consultancy (business services). The cross-sectional survey questionnaire used in this research was a specific tool designed to collect data that was not available elsewhere. The data was collected in 2010 during a world economic crisis when governments in Spain and Portugal were implementing severe measures to control public deficits. This macroeconomic and fiscal context may have influenced the respondents' perception of the entrepreneurial ecosystem, especially the economic and financial domains. 
The questionnaire methodology followed established procedures to ensure empirical validity and reliability. It should be stressed, however, that the survey was concerned with the perceptions of the respondents and not independently observable evidence of entrepreneurial behaviour. This subjective approach provides a unique perspective. First, the respondents in the survey were experts in their sector of activity to provide valid and useful information for our research. Second, perceptions are primary drivers of entrepreneurial activity - what individuals perceive are important determinants of subsequent behaviour.

\section{Data collection and reliability}

Using the online Yellow Pages, a database of firms in Spain and Portugal was created at the beginning of 2010. This method was deployed as there was no other database with the required information, and this online platform allowed search by location and sector of activity. The questionnaire was created to be used online and thus required respondents to have an e-mail account. All firms that did not had an e-mail account, on the yellow pages or on their institutional website, were excluded from the database. The final database included the information (name, activity, postal address, telephone and fax number, e-mail address, and (normally) URL) of 2,694 firms from Spain and 1,006 firms from Portugal. The definition of 'firm' adopted in conducting this research was a legal entity which has at least one employee, thus excluding self-employed people from the study. The 3,700 firms were contacted by e-mail, requesting their participation in the online questionnaire; followed, if required, by a telephone reminder. In the case of the manufacturing sector in Madeira, which only had a total of 17 firms, a paper version of the questionnaire was delivered to each firm's premises.

A total of 595 completed surveys were collected from all four regions. The total response rate was of $16 \%$ : varying from $7.7 \%$ in Catalonia to $44.3 \%$ in Madeira. It is important to note that the participation of firms from the manufacturing sector was limited by their low access to information technology and that the higher response rate in Madeira was due to the help provided by the local chamber of commerce that encouraged firms to participate in the study. Nevertheless, despite the random selection, there were differences between regions regarding the response rate, which made it necessary to test for potential non-response bias. The Armstrong and Overton (1977) approach was used to estimate the non-response bias by comparing early respondents with late respondents (where late respondents were used as proxies for non-respondents). The MannWhitney $U$ test between these two groups of responses in all four regions did not reveal statistical significant differences. Additionally, a comparison between the sample structure with the overall population of firms shows that the respondent firms were representative of their localities.

\section{The survey instrument}

The questionnaire consisted of closed questions, divided into four sections (questionnaire available from the authors on request). In the first section, respondents were asked to provide demographic and financial information about their firm and social and demographic information about themselves. In the remaining sections, respondents were asked to use a five-point Likert scale to assess: in section two, the entrepreneurial ecosystem in their region; in section three, the most important factors in new firm formation in their sector of activity; and in section four, the major problems when creating a new firm in their sector of activity. The variables used in these sections were drawn from an in-depth literature review of the remote island limitations, entrepreneurial ecosystems, and of the factors, characteristics, and conditions that are fundamental to the new firm formation (e.g. Armington \& Acs, 2002; Choi \& Phan, 2006; Cromie, 1987; Davidsson, 1991; Dubini, 1989; Greve \& Salaff, 2003; Kirchhoff et al., 2007; Klappera et al., 2006; Reynolds et al., 1994; Sutaria \& Hicks, 2004; Tamásy, 2006). Although the questionnaire was created to provide information on the spatial variations in entrepreneurial ecosystems, it was built on the foundations of other successful surveys of business performance (Cosh \& Hughes, 2007; Cosh et al., 2008; Goodbody, 2002; OECD, 2004; Quince \& Whittaker, 2002): 
Table 1: Firms' sample composition $(\mathrm{N}=595)$.

\begin{tabular}{|c|c|c|c|c|c|c|c|c|c|c|c|}
\hline \multirow{3}{*}{ Firm } & & \multicolumn{2}{|c|}{ Total } & \multicolumn{4}{|c|}{ Rem ote islands } & \multicolumn{4}{|c|}{ Core regions } \\
\hline & & \multirow{2}{*}{$\begin{array}{r}\mathrm{N} \\
147\end{array}$} & \multirow{2}{*}{$\begin{array}{c}\% \\
24.7\end{array}$} & \multicolumn{2}{|c|}{ Canary } & \multicolumn{2}{|c|}{ Madeira } & \multicolumn{2}{|c|}{ Catalonia } & \multicolumn{2}{|c|}{ Lisbon } \\
\hline & $<6$ years & & & 31 & 22.6 & 29 & 22.7 & 28 & 20.4 & 59 & 30.6 \\
\hline \multirow{3}{*}{$\stackrel{\square}{\circ}$} & 6 to 10 years & 147 & 24.7 & 30 & 21.9 & 40 & 31.3 & 28 & 20.4 & 49 & 25.4 \\
\hline & 11 to 20 years & 177 & 29.7 & 52 & 38.0 & 39 & 30.5 & 34 & 24.8 & 52 & 26.9 \\
\hline & $>20$ years & 124 & 20.8 & 24 & 17.5 & 20 & 15.6 & 47 & 34.3 & 33 & 17.1 \\
\hline \multirow{3}{*}{ 晃 } & Micro & 494 & 83.0 & 118 & 86.1 & 101 & 78.9 & 112 & 81.8 & 163 & 84.5 \\
\hline & Sm all & 90 & 15.1 & 18 & 13.1 & 27 & 21.1 & 21 & 15.3 & 24 & 12.4 \\
\hline & Medium/large & 11 & 1.8 & 1 & 0.7 & 0 & 0.0 & 4 & 2.9 & 6 & 3.1 \\
\hline \multirow{7}{*}{ 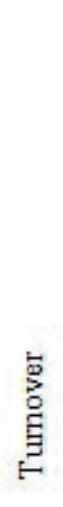 } & $<€ 150,001$ & 245 & 41.2 & 59 & 43.1 & 62 & 48.4 & 38 & 27.7 & 86 & 44.6 \\
\hline & $\begin{array}{l}€ 150,001 \text { to } \\
€ 500,000\end{array}$ & 157 & 26.4 & 42 & 30.7 & 22 & 17.2 & 46 & 33.6 & 47 & 24.4 \\
\hline & $\begin{array}{l}€ 500,001 \text { to } \\
€ 2,500,000\end{array}$ & 85 & 14.3 & 16 & 11.7 & 15 & 11.7 & 29 & 21.2 & 25 & 13.0 \\
\hline & $\begin{array}{l}€ 2,500,001 \text { to } \\
€ 5,000,000\end{array}$ & 21 & 3.5 & 2 & 1.5 & 6 & 4.7 & 8 & 5.8 & 5 & 2.6 \\
\hline & $\begin{array}{l}€ 5,000,001 \text { to } \\
€ 10,000,000\end{array}$ & 17 & 2.9 & 2 & 1.5 & 9 & 7.0 & 2 & 1.5 & 4 & 2.1 \\
\hline & $>€ 10,000,000$ & 11 & 1.8 & 0 & 0.0 & 3 & 2.3 & 3 & 2.2 & 5 & 2.6 \\
\hline & $\begin{array}{l}\text { Do not know/ } \\
\text { Not applicable }\end{array}$ & 59 & 9.9 & 16 & 11.7 & 11 & 8.6 & 11 & 8.0 & 21 & 10.9 \\
\hline \multirow{6}{*}{ 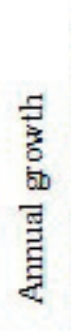 } & $<0 \%$ & 155 & 26.1 & 47 & 34.3 & 43 & 33.6 & 34 & 24.8 & 31 & 16.1 \\
\hline & $0 \%$ a $5 \%$ & 183 & 30.8 & 37 & 27.0 & 42 & 32.8 & 47 & 34.3 & 57 & 29.5 \\
\hline & $5.01 \%$ to $10 \%$ & 90 & 15.1 & 20 & 14.6 & 11 & 8.6 & 27 & 19.7 & 32 & 16.6 \\
\hline & $10.01 \%$ to $25 \%$ & 53 & 8.9 & 4 & 2.9 & 14 & 10.9 & 11 & 8.0 & 24 & 12.4 \\
\hline & $>25 \%$ & 43 & 7.2 & 8 & 5.8 & 7 & 5.5 & 6 & 4.4 & 22 & 11.4 \\
\hline & $\begin{array}{l}\text { Do not know/ } \\
\text { Not applicable }\end{array}$ & 71 & 11.9 & 21 & 15.3 & 11 & 8.6 & 12 & 8.8 & 27 & 14.0 \\
\hline \multirow{3}{*}{ 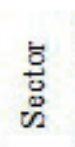 } & Manufacture & 94 & 15.8 & 15 & 10.9 & 12 & 9.4 & 33 & 24.1 & 34 & 17.6 \\
\hline & Tourism & 226 & 38.0 & 53 & 38.7 & 46 & 35.9 & 48 & 35.0 & 79 & 40.9 \\
\hline & Bus. Services & 275 & 46.2 & 69 & 50.4 & 70 & 54.7 & 56 & 40.9 & 80 & 41.5 \\
\hline
\end{tabular}

The characteristics of the sample

Table 1 shows the main characteristics of the survey sample. Approximately $80 \%$ of firms had been established for less than 20 years, and have less than 10 employees, demonstrating that the entrepreneurial ecosystem in these regions is mainly composed of micro firms with a small turnover. Table 2 shows that almost half of the respondents are the firms' founders-the entrepreneurs; and that one third of the respondents are female. The majority of the respondents are between 30 and 59 years old and have a College/University degree. An interesting finding is that Madeira has the highest percentage of younger entrepreneurs; this may suggest there is a lack of alternative job opportunities which may push young individuals towards entrepreneurship. 
Table 2: Respondents' sample composition $(\mathrm{N}=595)$.

\begin{tabular}{|c|c|c|c|c|c|c|c|c|c|c|c|}
\hline \multirow{2}{*}{\multicolumn{2}{|c|}{ Respondent }} & \multicolumn{2}{|c|}{ Total } & \multicolumn{4}{|c|}{ Remote islands } & \multicolumn{4}{|c|}{ Core regions } \\
\hline & & \multirow{2}{*}{$\frac{\mathrm{N}}{282}$} & \multirow{2}{*}{$\begin{array}{r}\% \\
47.4\end{array}$} & \multicolumn{2}{|c|}{ Canary } & \multicolumn{2}{|c|}{ Madeira } & \multicolumn{2}{|c|}{ Catalonia } & \multicolumn{2}{|c|}{ Lisbon } \\
\hline \multirow{3}{*}{ 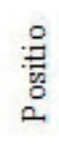 } & Founder & & & 65 & 47.4 & 51 & 39.8 & 71 & 51.8 & 95 & 49.2 \\
\hline & Partner & 121 & 20.3 & 23 & 16.8 & 32 & 25.0 & 24 & 17.5 & 42 & 21.8 \\
\hline & Director & 192 & 32.3 & 49 & 35.8 & 45 & 35.2 & 42 & 30.7 & 56 & 29.0 \\
\hline \multirow{2}{*}{ 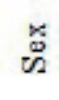 } & Female & 194 & 32.6 & 42 & 30.7 & 43 & 33.6 & 45 & 32.8 & 64 & 33.2 \\
\hline & Male & 401 & 67.4 & 95 & 69.3 & 85 & 66.4 & 92 & 67.2 & 129 & 66.8 \\
\hline \multirow{5}{*}{ 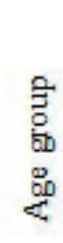 } & 20 to 29 years & 31 & 5.2 & 2 & 1.5 & 8 & 6.3 & 4 & 2.9 & 17 & 8.8 \\
\hline & 30 to 39 years & 190 & 31.9 & 38 & 27.7 & 55 & 43.0 & 34 & 24.8 & 63 & 32.6 \\
\hline & 40 to 49 years & 208 & 35.0 & 54 & 39.4 & 38 & 29.7 & 54 & 39.4 & 62 & 32.1 \\
\hline & 50 to 59 years & 123 & 20.7 & 35 & 25.5 & 17 & 13.3 & 30 & 21.9 & 41 & 21.2 \\
\hline & More than 59 years & 43 & 7.2 & 8 & 5.8 & 10 & 7.8 & 15 & 10.9 & 10 & 5.2 \\
\hline \multirow{5}{*}{ 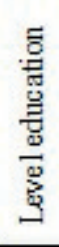 } & First School & 4 & 0.7 & 3 & 2.2 & 0 & 0.0 & 1 & 0.7 & 0 & 0.0 \\
\hline & Middle School & 15 & 2.5 & 4 & 2.9 & 0 & 0.0 & 9 & 6.6 & 2 & 1.0 \\
\hline & High School & 149 & 25.0 & 29 & 21.2 & 44 & 34.4 & 26 & 19.0 & 50 & 25.9 \\
\hline & College/university & 320 & 53.8 & 75 & 54.7 & 65 & 50.8 & 72 & 52.6 & 108 & 56.0 \\
\hline & Postgraduate & 107 & 18.0 & 26 & 19.0 & 19 & 14.8 & 29 & 21.2 & 33 & 17.1 \\
\hline
\end{tabular}

\section{Results and discussion}

\section{Hypotheses 1 and 2: Canary Islands versus Catalonia}

To test for statistical differences between the characteristics of the ecosystems in remote islands and core regions we use the non-parametric Mann-Whitney $U$ test. Table 3 shows that there are statistically significant differences in 12 of the 15 factors that characterize the entrepreneurial ecosystem, when comparing the assessment made by firms in Canary Islands with those in Catalonia. The majority of the factors have higher mean scores in Catalonia, the exception being fiscal incentives, which may reflect a higher public policy support in the remote region. Overall, the results support Hypothesis 1.

Table 3 also shows that there are significant differences between two sectors in the ease to identify a business opportunity: manufacturing achieved a higher mean score in Catalonia; whereas tourism obtained the higher mean score in the Canary Islands. These results, therefore, only partially support Hypothesis 2.

\section{Hypotheses 1 and 2: Madeira versus Lisbon}

Table 4 shows statistically significant differences in a total of 10 factors in the assessment of the entrepreneurial ecosystem made by firms in Madeira compared with those in Lisbon. The factors obtained higher mean scores in Lisbon, with two exceptions: social attitudes encouraging new entrepreneurs and fiscal incentives. Overall, the results support Hypothesis 1. When comparing ease to identify a business opportunity assessment, in all three sectors, there are no statistically significant differences. Therefore, regarding the comparison between Madeira and Lisbon, the results do not support Hypothesis 2. 
Table 3: Mann-Whitney $U$ test results to the assessment of the entrepreneurial ecosystem in Canary Islands and Catalonia.

\begin{tabular}{|c|c|c|c|c|c|c|}
\hline Domains & Region & Mean & SD & $\begin{array}{c}\text { Mean } \\
\text { rank }\end{array}$ & $\begin{array}{l}\text { Mann- } \\
\text { Whitney }\end{array}$ & $\mathrm{Z}$ \\
\hline \multicolumn{7}{|l|}{ Social and demographic } \\
\hline \multirow{2}{*}{$\begin{array}{l}\text { Social attitude encourages new } \\
\text { entrepreneurs }\end{array}$} & Canary & 2.5 & 1 & 125.8 & \multirow{2}{*}{$7,781.5$} & \multirow{2}{*}{$-2.54^{*}$} \\
\hline & Catalonia & 2.8 & 1 & 149.2 & & \\
\hline \multirow{2}{*}{$\begin{array}{l}\text { Entrepreneurs have good social } \\
\text { networks }\end{array}$} & Canary & 2.4 & 1 & 121.16 & \multirow{2}{*}{7,146} & - \\
\hline & Catalonia & 2.9 & 1 & 153.84 & & $3.56^{* *}$ \\
\hline \multirow{2}{*}{ Good level of schooling and skills } & Canary & 2.5 & 1 & 103.43 & \multirow{2}{*}{$4,716.5$} & - \\
\hline & Catalonia & 3.4 & 0.9 & 171.57 & & $7.43^{* * *}$ \\
\hline \multirow{2}{*}{$\begin{array}{l}\text { Adequate business background } \\
\text { experience by entrepreneur }\end{array}$} & Canary & 2.7 & 0.9 & 116.32 & \multirow{2}{*}{$6,482.5$} & \multirow{2}{*}{$-6.65^{* *}$} \\
\hline & Catalonia & 3.2 & 0.9 & 158.68 & & \\
\hline \multirow{2}{*}{ Good level of demand } & Canary & 2.4 & 0.9 & 124.81 & \multirow[b]{2}{*}{$7,645.5$} & \multirow[b]{2}{*}{$-2.79^{*}$} \\
\hline & Catalonia & 2.7 & 0.9 & 150.19 & & \\
\hline \multicolumn{7}{|l|}{ Economic } \\
\hline \multirow{2}{*}{$\begin{array}{l}\text { Good level of growth in income } \\
\text { availability }\end{array}$} & Canary & 1.9 & 0.8 & 119.08 & \multirow{2}{*}{6,861} & - \\
\hline & Catalonia & 2.3 & 0.9 & 155.92 & & $4.16^{\text {** }}$ \\
\hline \multirow{2}{*}{ Supportive industrial structure } & Canary & 2.2 & 0.9 & 118.09 & \multirow{2}{*}{$6,725.5$} & \\
\hline & Catalonia & 2.7 & 0.9 & 156.91 & & $4.31^{\text {*** }}$ \\
\hline \multicolumn{7}{|l|}{ Technological } \\
\hline \multirow{2}{*}{ Efficient knowledge exchange } & Canary & 2.7 & 0.9 & 117.65 & \multirow{2}{*}{$6,665.5$} & - \\
\hline & Catalonia & 3.2 & 1 & 157.35 & & $4.36^{* *}$ \\
\hline \multirow{2}{*}{ Public sector invests in R\&D } & Canary & 2.5 & 0.9 & 130.06 & \multirow{2}{*}{8,365} & -164 \\
\hline & Catalonia & 2.6 & 0.9 & 144.94 & & -1.64 \\
\hline & Canary & 2.6 & 0.8 & 110 & & - \\
\hline Private sector invests in R\&D & Catalonia & 3.2 & 0.8 & 165 & 5,617 & $6.08^{* * *}$ \\
\hline Financial & & & & & & \\
\hline & Canary & 2.2 & 0.9 & 124.72 & & \\
\hline Good availability of capital & Catalonia & 2.5 & 1.1 & 150.28 & 7,634 & $-2.81^{*}$ \\
\hline & Canary & 3.1 & 1.2 & 169.58 & & - \\
\hline Fiscal incentives & Catalonia & 2.1 & 1 & 105.42 & 4,989 & $6.90^{* *}$ \\
\hline Infrastructural & & & & & & \\
\hline Good communication and transnort & Canary & 2.9 & 1.1 & 121.47 & & \\
\hline Good communication and transport & Catalonia & 3.3 & 1.1 & 153.53 & 7,189 & $3.54^{* *}$ \\
\hline Good business supportive services & Canary & 2.5 & 1 & 132.6 & $8,713.5$ & -1.07 \\
\hline Policy & Catalonia & 2.6 & 1 & 142.4 & & \\
\hline & Canary & 2.2 & 0.9 & 133.15 & 885 & 007 \\
\hline Supportive governmental policies & Catalonia & 2.4 & 0.9 & 141.85 & $8, / 88.5$ & -0.97 \\
\hline Easy to identify a business opportunity & & & & & & \\
\hline & Canary & 2.1 & 1.2 & 17.43 & & \\
\hline Manufacturing & Catalonia & 2.8 & 0.8 & 27.71 & $1,41.5$ & $-2.48^{*}$ \\
\hline & Canary & 3.0 & 1 & 57.1 & & $-230 \%$ \\
\hline Tourism & Catalonia & 2.6 & 0.9 & 44.26 & 948.5 & $-2.30^{*}$ \\
\hline Business services & Canary & 2.4 & 0.9 & 64.76 & 18085 & -0.65 \\
\hline Business services & Catalonia & 2.7 & 0.8 & 60.79 & $1,808.5$ & -0.03 \\
\hline
\end{tabular}

${ }^{*} \mathrm{p}<0.05,{ }^{* *} \mathrm{p}<0.001$ (two tailed) 
Table 4: Mann-Whitney $U$ test results to the assessment of the entrepreneurial ecosystem in Madeira and Lisbon.

\begin{tabular}{|c|c|c|c|c|c|c|}
\hline Domains & Region & Mean & SD & $\begin{array}{l}\text { Mean } \\
\text { Rank }\end{array}$ & $\begin{array}{l}\text { Mann- } \\
\text { Whitney }\end{array}$ & $\mathrm{Z}$ \\
\hline \multicolumn{7}{|l|}{ Social and demographic } \\
\hline Social attitude encourages new & Madeira & 3.1 & 1 & 187.57 & \multirow{2}{*}{$8,951.5$} & \multirow{2}{*}{$-4.37 * *$} \\
\hline entrepreneurs & Lisbon & 2.6 & 1 & 143.38 & & \\
\hline \multirow{2}{*}{$\begin{array}{l}\text { Entrepreneurs have good social } \\
\text { networks }\end{array}$} & Madeira & 3 & 1 & 166.21 & \multirow{2}{*}{$11,685.5$} & \multirow{2}{*}{-0.86} \\
\hline & Lisbon & 2.9 & 1 & 157.55 & & \\
\hline \multirow{2}{*}{ Good level of schooling and skills } & Madeira & 2.9 & 1 & 129.72 & \multirow{2}{*}{$8,348.5$} & \multirow{2}{*}{$-5.21^{* *}$} \\
\hline & Lisbon & 3.4 & 0.9 & 181.74 & & \\
\hline \multirow{2}{*}{$\begin{array}{l}\text { Adequate business background } \\
\text { experience by entrepreneur }\end{array}$} & Madeira & 2.9 & 0.9 & 146.46 & \multirow{2}{*}{$10,491.5$} & \multirow{2}{*}{$-2.42^{*}$} \\
\hline & Lisbon & 3.1 & 0.9 & 170.64 & & \\
\hline \multirow{2}{*}{ Good level of demand } & Madeira & 3.3 & 1 & 154.15 & \multirow{2}{*}{$11,475.5$} & \multirow{2}{*}{-1.17} \\
\hline & Lisbon & 3.4 & 0.9 & 165.54 & & \\
\hline \multicolumn{7}{|l|}{ Economic } \\
\hline Good level of growth in income & Madeira & 2.2 & 0.8 & 144.49 & \multirow{2}{*}{$10,238.5$} & \multirow{2}{*}{$-2.8^{*}$} \\
\hline availability & Lisbon & 2.5 & 0.9 & 171.95 & & \\
\hline \multirow{2}{*}{ Supportive industrial structure } & Madeira & 2 & 0.9 & 135.38 & \multirow{2}{*}{9,073} & \multirow{2}{*}{$-4.23^{* *}$} \\
\hline & Lisbon & 2.5 & 0.9 & 177.99 & & \\
\hline \multicolumn{7}{|l|}{ Technological } \\
\hline \multirow{2}{*}{ Efficient knowledge exchange } & Madeira & 2.8 & 1 & 151.34 & \multirow{2}{*}{11,116} & \multirow{2}{*}{-1.59} \\
\hline & Lisbon & 3 & 1 & 167.4 & & \\
\hline Public sector invests in R\&D & Madeira & 2.6 & 1 & 154.01 & & -1.16 \\
\hline Public sector invests in KaD & Lisbon & 2.7 & 0.9 & 165.64 & $11,45 /$ & -1.16 \\
\hline Private sector invests in R\&D & Madeira & 2.5 & 1 & 133.29 & 8.805 & $-4.56 * *$ \\
\hline Private sector invess in KoD & Lisbon & 3 & 0.9 & 179.38 & 8,803 & -4.50 \\
\hline Financial & & & & & & \\
\hline Good availability of capital & Madeira & 2.4 & 0.9 & 139.82 & 9.641 & $-3.48 * *$ \\
\hline & Lisbon & 2.7 & 1 & 175.05 & & \\
\hline Fiscal incentives & Madeira & 2.6 & 1.2 & 189.88 & 8.656 & $-4.77 * *$ \\
\hline & Lisbon & 2 & 0.9 & 141.85 & & $-4.77 \mathrm{~m}$ \\
\hline Infrastructural & & & & & & \\
\hline Good communication and transport & Madeira & 3.8 & 1 & 150.11 & $10,958.5$ & $-2.02 *$ \\
\hline & Lisbon & 4 & 0.8 & 168.22 & $10,800.0$ & $-2.02^{\circ}$ \\
\hline Good business supportive services & Madeira & 3.1 & 1 & 158 & 11,968 & -0.5 \\
\hline 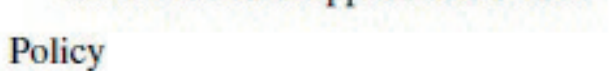 & Lisbon & 3.2 & 1 & 162.99 & & \\
\hline Supportive governmental policies & Madeira & 3 & 1.1 & 180.43 & 0865 & \\
\hline & Lisbon... & 2.6. & $1 . .$. & 148.11. & 9,865 & $-3.11 \%$ \\
\hline Easy to identify a business opportunity & & & & & & \\
\hline Manufacturing & Madeira & 2.5 & 1.2 & 22.25 & 189 & -0.4 \\
\hline & Lisbon & 2.6 & 0.9 & 23.94 & 107 & \\
\hline Tourism & Madeira & 2.6 & 1 & 59.48 & 1.655 & -0.87 \\
\hline & Lisbon & 2.8 & 1 & 65.05 & & \\
\hline Business services & Madeira & 2.8 & 0.9 & 76.47 & 2,732 & -0.27 \\
\hline
\end{tabular}

${ }^{*} \mathrm{p}<0.05,{ }^{* *} \mathrm{p}<0.001$ (two tailed) 


\section{Hypothesis 3: Important factors in new firm formation-Remote Islands versus Core Regions}

The Kruskall-Wallis $\mathrm{H}$ test was used to check for statistically significant differences between remote islands and core region in the assessment of the most important factors and major problems in new firm formation, by region and sector of activity. To interpret Tables 5 and 6 there are three important points to note. First, an asterisk in the first line of a variable indicates statistical significant differences between all sectors within the same region in that specific variable. Second, an asterisk in the mean score line of a variable indicates statistical significant differences between all regions. Third, an asterisk in last column (average score) of a variable indicate statistical significant differences between all regions within the same sector.

In Table 5 the factors with the highest scores are: identified a business opportunity; background experience and knowledge of the business; have the necessary capital; and have a good business idea. The evidence shows that the assessment of the most important factors for new firm formation are similar across the different regions.

Deepening the analysis, it is possible to identify significant statistical differences between all regions in five of the 11 factors, including: identifying a business opportunity is more important for new firms in Catalonia and Lisbon compared to the remote islands, and lack of other jobs are relatively more important in the Canary Islands, which may reflect the high structural unemployment in the region. Another interesting result is that the majority of mean scores of the answers diverge from the middle of the scale suggesting that entrepreneurs consider that a wide range of factors are important for new firm formation-reflecting both individual characteristics and those of the broader ecosystem.

Regarding the results by sector, firms in the manufacturing sector consider that formal educational levels are an important factor for new firm formation. Looking at the three factors used to assess governmental policy; only one had statistical significantly differences, the attractive fiscal incentives, which obtained a higher score in the Canary Islands. Therefore, the results only partially support Hypothesis 3.

Hypothesis 4: The major problems in new firm formation — remote islands versus core regions

The assessment of the major problems in new firm formation are presented in Table 6. In general, including by sector, firms in all regions highlight the following problems: finding sources of finance and the cost of finance. However, these results may reflect the context of economic crisis faced by Spain and Portugal during the data collection period when access to financial capital was squeezed. There are statistically significant differences between the four regions in eight of the 17 problems. As expected, firms in Catalonia and Lisbon consider that high geographic distance from customers and high geographic distance from suppliers are a minor problem. However, the problems of management expertise, writing a formal business plan, and coping with regulation obtained higher mean scores in core regions. 
Table 5: Most important factors in new firm formation (mean scores).

\begin{tabular}{|c|c|c|c|c|c|c|}
\hline \multirow{2}{*}{ Factors } & \multirow{2}{*}{ Activity } & \multicolumn{2}{|c|}{ Remote islands } & \multicolumn{2}{|c|}{ Core regions } & \multirow{2}{*}{$\begin{array}{c}\text { Average } \\
\text { score }\end{array}$} \\
\hline & & Canary & Madeira & Catalonia & Lisbon & \\
\hline \multirow{4}{*}{$\begin{array}{l}\text { Help from family } \\
\text { and friends }\end{array}$} & Manufacturing & 3.3 & 3.5 & 3.5 & 3.6 & 3.5 \\
\hline & Tourism & 3.3 & 3.3 & 3.4 & 3.2 & 3.3 \\
\hline & Business services & 3.3 & 3.2 & 3.4 & 3.3 & 3.3 \\
\hline & Mean score & 3.3 & 3.3 & 3.4. & 3.3. & \\
\hline \multirow{4}{*}{$\begin{array}{l}\text { Identified a } \\
\text { Business } \\
\text { opportunity }\end{array}$} & Manufacturing & 4.1 & 4.0 & 4.2 & $4.1^{*}$ & 4.1 \\
\hline & Tourism & 3.9 & 4.1 & 4.2 & 4.3 & $4.1^{* *}$ \\
\hline & Business services & 4.0 & 4.0 & 4.1 & 4.1 & 4.1 \\
\hline & Mean score & $4.0^{* *}$ & 4.0 & 4.2 & 4.2 & \\
\hline \multirow{4}{*}{$\begin{array}{l}\text { Formal } \\
\text { Educational } \\
\text { level }\end{array}$} & Manufacturing & $4.4^{*+4}$ & 4.3 & 4.1 & $3.9^{*+}$ & $4.2^{\circ}$ \\
\hline & Tourism & 3.7 & 3.7 & 3.7 & 3.7 & 3.7 \\
\hline & Business services & 3.8 & 3.9 & 4.0 & 4.1 & 4.0 \\
\hline & Mean score & 3.8 & 3.9 & 3.9 & 3.9 & \\
\hline \multirow{4}{*}{$\begin{array}{l}\text { Background } \\
\text { experience }\end{array}$} & Manufacturing & 4.5 & 4.3 & 4.5 & 4.4 & 4.4 \\
\hline & Tourism & 4.2 & 4.5 & 4.2 & 4.5 & 4.4 \\
\hline & Business services & 4.1 & 4.3 & 4.2 & 4.5 & $4.3^{*}$ \\
\hline & Mean score & $4.2^{*}$ & 4.4 & 4.3 & 4.5. & \\
\hline \multirow{4}{*}{$\begin{array}{l}\text { Support from } \\
\text { governmental } \\
\text { programmes }\end{array}$} & Manufacturing & 3.5 & 3.7 & 3.5 & 3.6 & 3.6 \\
\hline & Tourism & 3.5 & 3.6 & 3.4 & 3.2 & 3.4 \\
\hline & Business services & 3.2 & 3.5 & 3.1 & 3.2 & $3.3^{*}$ \\
\hline & Mean score & 3.3 & 3.6. & 3.3 & 3.3. & \\
\hline \multirow{4}{*}{$\begin{array}{l}\text { Low legal } \\
\text { requirements }\end{array}$} & Manufacturing & 3.6 & 3.6 & 3.6 & 3.5 & 3.6 \\
\hline & Tourism & 3.7 & 3.5 & 3.8 & 3.5 & 3.6 \\
\hline & Business services & 3.5 & 3.6 & 3.3 & 3.5 & 3.5 \\
\hline & Mean score & 3.6 & 3.5. & 3.5 & 3.5. & \\
\hline \multirow{4}{*}{$\begin{array}{l}\text { Have the } \\
\text { Necessary } \\
\text { capital }\end{array}$} & Manufacturing & 4.6 & 4.5 & 4.4 & $4.5^{\circ}$ & 4.5 \\
\hline & Tourism & 4.2 & 4.3 & 4.4 & 4.3 & 4.3 \\
\hline & Business services & 4.2 & 4.2 & 4.2 & 4.1 & 4.2 \\
\hline & Mean score & 4.2 & 4.2. & 4.3. & 4.3. & \\
\hline \multirow{4}{*}{$\begin{array}{l}\text { Attractive } \\
\text { Fiscal } \\
\text { incentives }\end{array}$} & Manufacturing & 3.7 & 3.6 & $3.7^{*}$ & 3.7 & 3.7 \\
\hline & Tourism & 3.9 & 3.7 & 3.8 & 3.4 & 3.7 \\
\hline & Business services & 3.9 & 3.6 & 3.3 & 3.2 & $3.5^{* *}$ \\
\hline & Mean score & $3.9^{* *}$ & 3.6 & 3.6 & 3.4 & \\
\hline \multirow{4}{*}{$\begin{array}{l}\text { Have a } \\
\text { good } \\
\text { business } \\
\text { idea }\end{array}$} & Manufacturing & 4.3 & $4.2^{\circ}$ & 4.4 & 4.3 & 4.3 \\
\hline & Tourism & 4.2 & 4.6 & 4.4 & 4.5 & $4.4^{* *}$ \\
\hline & Business services & 4.3 & 4.3 & 4.3 & 4.3 & 4.3 \\
\hline & Mean score & 4.3 & 4.4. & 4.4 & 4.4. & \\
\hline \multirow{4}{*}{$\begin{array}{l}\text { Entrepreneurship } \\
\text { runs in family }\end{array}$} & Manufacturing & 2.9 & 2.7 & 3.4 & 3.4 & 3.1 \\
\hline & Tourism & 3.3 & 3.0 & 3.3 & 3.1 & 3.2 \\
\hline & Business services & 3.6 & 3.2 & 3.4 & 3.4 & 3.4 \\
\hline & Mean score & $3.4^{* *}$ & 3.1 & 3.4. & 3.3. & \\
\hline \multirow{4}{*}{$\begin{array}{l}\text { Lack of } \\
\text { other jobs/ } \\
\text { opportunities }\end{array}$} & Manufacturing & 3.5 & $3.1^{* 4}$ & 3.2 & 3.2 & 3.3 \\
\hline & Tourism & 3.6 & 2.9 & 3.4 & 3.3 & $3.3^{* *}$ \\
\hline & Business services & 3.8 & 3.5 & 3.3 & 3.1 & $3.4^{* *}$ \\
\hline & Mean score & $3.7^{* *}$ & 3.2 & 3.3 & 3.2 & \\
\hline
\end{tabular}

${ }^{*} p<0.05,{ }^{* *} p<0.001$ 
Table 6: Major problems in new firm formation (mean scores)

\begin{tabular}{|c|c|c|c|c|c|c|}
\hline \multirow{2}{*}{ Problems } & \multirow{2}{*}{ Activity } & \multicolumn{2}{|c|}{ Remote islands } & \multicolumn{2}{|c|}{ Core regions } & \multirow{2}{*}{$\begin{array}{l}\text { Average } \\
\text { score }\end{array}$} \\
\hline & & Canary & Madeira & Catalonia & Lisbon & \\
\hline \multirow{4}{*}{$\begin{array}{l}\text { Management } \\
\text { expertise }\end{array}$} & Manufacturing & $2.2^{* *}$ & 2.7 & $3.4^{* 4}$ & 2.7 & $2.8^{*}$ \\
\hline & Tourism & 2.3 & 2.5 & 2.5 & 2.9 & 2.6 \\
\hline & Business services & 2.9 & 2.8 & 3.1 & 2.9 & 2.9 \\
\hline & Mean score & 2.6 & 2.7 & 2.9 & 2.9 & \\
\hline \multirow{4}{*}{$\begin{array}{l}\text { Writing a } \\
\text { formal } \\
\text { business plan }\end{array}$} & Manufacturing & 2.3 & 2.4 & $3.2^{*}$ & 2.7 & 2.7 \\
\hline & Tourism & 2.7 & 2.8 & 2.4 & 2.9 & 2.7 \\
\hline & Business services & 2.8 & 2.7 & 2.9 & 3.1 & 2.9 \\
\hline & Mean score & 2.7 & 2.7 & 2.8 & 3.0 & \\
\hline \multirow{4}{*}{$\begin{array}{l}\text { Finding } \\
\text { premises }\end{array}$} & Manufacturing & 3.2 & $3.3^{3 . *}$ & 3.0 & 3.0 & 3.1 \\
\hline & Tourism & 2.6 & 3.4 & 2.6 & 2.8 & $2.9^{*}$ \\
\hline & Business services & 2.6 & 2.6 & 2.4 & 2.6 & 2.6 \\
\hline & Mean score & 2.7 & 2.9 & 2.6 & 2.8 & \\
\hline \multirow{4}{*}{$\begin{array}{l}\text { Cost of } \\
\text { premises }\end{array}$} & Manufacturing & 3.9 & 3.3 & 3.8 & 3.7 & 3.7 \\
\hline & Tourism & 3.4 & 3.7 & 3.7 & 3.4 & 3.6 \\
\hline & Business services & 3.5 & 3.6 & 3.4 & 3.6 & 3.5 \\
\hline & Mean score & 3.5 & .3 .6 & 3.6. & 3.5. & \\
\hline \multirow{4}{*}{$\begin{array}{l}\text { Finding } \\
\text { source of } \\
\text { finance }\end{array}$} & Manufacturing & 4.3 & 3.8 & 4.3 & 4.1 & 4.1 \\
\hline & Tourism & 4.0 & 4.2 & 4.3 & 3.8 & $4.1^{*}$ \\
\hline & Business services & 4.2 & 3.9 & 4.1 & 3.9 & 4.0 \\
\hline & Mean score & $41^{*}$ & ..... & 4.2. & 3.9. & \\
\hline \multirow{4}{*}{$\begin{array}{l}\text { Cost of } \\
\text { finance }\end{array}$} & Manufacturing & $4.4^{*}$ & $\dddot{4} .1$ & 3.9 & 3.9 & 4.1 \\
\hline & Tourism & 3.7 & 4.1 & 4.2 & 3.8 & $4.0^{\circ}$ \\
\hline & Business services & 3.9 & 3.8 & 3.7 & 3.9 & 3.8 \\
\hline & Mean score & 3.9 & 3.9 & 3.9 & 3.9 & \\
\hline \multirow{4}{*}{$\begin{array}{l}\text { Finding } \\
\text { customers }\end{array}$} & Manufacturing & 3.5 & 3.5 & 3.2 & $3.3^{*}$ & 3.4 \\
\hline & Tourism & 3.1 & 3.6 & 3.5 & 3.2 & 3.4 \\
\hline & Business services & 3.5 & 3.9 & 3.6 & 3.8 & 3.7 \\
\hline & Mean score & $3.3^{*}$ & 3.7. & 3.5 & 3.4. & \\
\hline \multirow{4}{*}{$\begin{array}{l}\text { Availability } \\
\text { of skilled } \\
\text { workers }\end{array}$} & Manufacturing & 3.9 & $\dddot{m}^{2} \cdot 3^{*}$ & 3.7 & $3.8^{*}$ & 3.9 \\
\hline & Tourism & 3.3 & 2.9 & 3.6 & 3.1 & 3.2 \\
\hline & Business services & 3.7 & 3.3 & 3.5 & 3.3 & 3.5 \\
\hline & Mean score & 3.5 & 3.2. & 3.6 & 3.3. & \\
\hline \multirow{4}{*}{$\begin{array}{l}\text { Employee } \\
\text { costs }\end{array}$} & Manufacturing & 3.9 & 3.2 & 3.6 & 3.4 & 3.5 \\
\hline & Tourism & 3.4 & 3.5 & 3.7 & 3.4 & 3.5 \\
\hline & Business services & 3.7 & 3.5 & 3.4 & 3.5 & 3.5 \\
\hline & Mean score & 3.6 & 3.5 & 3.6 & 3.4 & \\
\hline \multirow{4}{*}{$\begin{array}{l}\text { Coping } \\
\text { with } \\
\text { regulation }\end{array}$} & Manufacturing & 3.1 & 2.9 & $3.8^{*}$ & $3.6^{*}$ & 3.4 \\
\hline & Tourism & 3.4 & 3.4 & 3.6 & 3.5 & 3.5 \\
\hline & Business services & 3.1 & 3.1 & 3.1 & 2.9 & 3.1 \\
\hline & Mean score & 3.2 & 3.2. & 3.4 & 3.3. & \\
\hline \multirow{4}{*}{$\begin{array}{l}\text { Competing } \\
\text { with other } \\
\text { firms }\end{array}$} & Manufacturing & $3.9^{*}$ & $2.3^{*}$ & 3.2 & 2.9 & $3.1^{\prime \prime}$ \\
\hline & Tourism & 2.8 & 3.8 & 3.4 & 3.1 & $3.3^{* *}$ \\
\hline & Business services & 3.1 & 3.5 & 3.1 & 3.4 & 3.3 \\
\hline & Mean score & $3.1^{*}$ & 3.5 & 3.2 & 3.2. & \\
\hline
\end{tabular}




\begin{tabular}{|c|c|c|c|c|c|c|}
\hline \multirow{4}{*}{$\begin{array}{l}\text { Lack of } \\
\text { advice/ } \\
\text { support }\end{array}$} & Manufacturing & 3.2 & 2.8 & $3.3^{* *}$ & $3.4^{*}$ & 3.2 \\
\hline & Tourism & 3.2 & 3.0 & 3.2 & 3.0 & 3.1 \\
\hline & Business services & 2.9 & 2.7 & 2.6 & 2.7 & 2.7 \\
\hline & Mean score & 3.0 & 2.8 & 3.0 & 2.9 & \\
\hline \multirow{4}{*}{$\begin{array}{l}\text { High } \\
\text { transportation } \\
\text { costs }\end{array}$} & Manufacturing & $3.9^{* *}$ & $3.4^{* *}$ & $3.1^{* *}$ & $3.1^{* *}$ & 3.4 \\
\hline & Tourism & 2.7 & 3.7 & 2.7 & 2.7 & $3.0^{* *}$ \\
\hline & Business services & 2.9 & 2.7 & 2.1 & 2.3 & $2.5^{*}$ \\
\hline & Mean score & $2.9^{* *}$ & 3.1 & 2.5 & 2.6 & \\
\hline \multirow{4}{*}{$\begin{array}{l}\text { Small } \\
\text { regional } \\
\text { market }\end{array}$} & Manufacturing & 3.3 & 3.4 & 2.8 & 2.8 & 3.1 \\
\hline & Tourism & 3.0 & 3.9 & 2.8 & 2.8 & $3.1^{* *}$ \\
\hline & Business services & 3.4 & 3.9 & 2.5 & 2.8 & $3.2^{* *}$ \\
\hline & Mean score & $3.2^{* *}$ & 3.8 & 2.7 & 2.8 & \\
\hline \multirow{4}{*}{$\begin{array}{l}\text { Low } \\
\text { economic } \\
\text { diversity in } \\
\text { the region }\end{array}$} & Manufacturing & 3.7 & 3.4 & 2.7 & 2.5 & $3.1^{* *}$ \\
\hline & Tourism & 3.2 & 3.8 & 2.6 & 2.4 & $3.0^{* *}$ \\
\hline & Business services & 3.3 & 3.6 & 2.5 & 2.3 & $2.9^{* *}$ \\
\hline & Mean score & $3.3^{* *}$ & 3.7 & 2.6 & 2.4 & \\
\hline \multirow{4}{*}{$\begin{array}{l}\text { High } \\
\text { geographic } \\
\text { distance } \\
\text { from } \\
\text { customers }\end{array}$} & Manufacturing & 2.5 & 3.0 & 2.0 & 2.1 & 2.4 \\
\hline & Tourism & 2.3 & 2.7 & 2.0 & 1.9 & $2.2^{* *}$ \\
\hline & Business services & 2.5 & 2.4 & 2.0 & 1.8 & $2.2^{* *}$ \\
\hline & Mean score & $2.4^{* *}$ & 2.6 & 2.0 & 1.9. & \\
\hline \multirow{4}{*}{$\begin{array}{l}\text { High } \\
\text { geographic } \\
\text { distance } \\
\text { from } \\
\text { suppliers }\end{array}$} & Manufacturing & $3.9^{* *}$ & 3.6 & 2.1 & 2.0 & $2.9^{* *}$ \\
\hline & Tourism & 2.5 & 2.5 & 1.9 & 1.8 & $2.2^{* *}$ \\
\hline & Business services & 2.7 & 2.4 & 1.8 & 1.7 & $2.2^{* *}$ \\
\hline & Mean score & $2.7^{* *}$ & 2.6 & 1.9 & 1.8 & \\
\hline
\end{tabular}

$* \mathrm{p}<0.05, * * \mathrm{p}<0.001$

Despite having relatively low scores, the five problems linked to geographic and economic constraints obtained a statistically higher mean score in the remote islands compared to core regions. This suggests that the specific locational characteristics of remote islands impose more problems for new firm formation in comparison to core regions, therefore supporting Hypothesis 4.

\section{Conclusions and implications for policy}

Much of the corpus of knowledge on regional development suggests that new firm formation is less challenging in core regions compared to remote islands, as in the former location there is both easier access to resources and there are institutions that facilitate transactional relationships. The analysis of the evidence of this study supports Hypotheses 1 indicating that firms in remote islands do perceive that they operate in a less favourable entrepreneurial ecosystem compared to the assessment of firms in core regions. This suggests that the external environmental conditions in remote islands may discourage new firm formation. Firms in core regions, such as Catalonia and Lisbon, perceive a more favourable social and demographic domain due to a range of factors. First, a better social network, possibly reflecting the movement of people and information into these regions, as well as more established institutions. Second, firms in core regions perceive that they have access to highly educated workers - this is consistent with published statistics which show a higher percentage of people with university degrees in Catalonia and Lisbon (in 2010). Third, the relatively superior business experience in the core regions probably reflects the greater exposure to different occupational compositions.

Firms in core regions perceive their economic and infrastructural domains to be more favourable compared to firms in the remote islands, reflecting the contrast in the levels of 
economic development. Furthermore, firms in remote islands assigned lower scores to most of the factors in the technological domain compared to firms in core regions. This is consistent with Baldacchino's (1999) argument that remote (and island) regions suffer from inadequate access to technology; and reflects the lower levels of public and private sector investment in research and development $(\mathrm{R} \& \mathrm{D})$ in these regions.

Overall, evidence from the survey shows that there are statistical significant differences between these remote islands and core regions in the majority of the six domains of the entrepreneurial ecosystem, and that the majority of the factors in these domains were considered to be more favourable in the two core regions, supporting much of the literature on entrepreneurial ecosystems and regional development. It should be stressed, however, that there are some aspects of the entrepreneurial ecosystem that were more favourable in the remote islands. Firms in remote islands perceive that support from governmental programmes (in the case of Madeira) and fiscal incentives were higher than assessed by firms in core regions. These findings show that local governments' actions will have an important role to play supporting local entrepreneurs in regions where distance, peripherality, and small size (and islandness) are major problems.

Regional development theory stresses that: limited access to resources, high transportation costs, and the difficulty in obtaining economies of scale in remote islands may limit the development of some sectors such as manufacturing. Additionally, the entrepreneurship literature emphasizes that the entrepreneur's perception of the scarcity or abundance of critical resources needed within a region will be a crucial element in his/her decision to create a new firm (Begley et al., 2005). Thus, the service sector, especially tourism, is perceived as offering more business opportunities to entrepreneurs in island regions. The analysis disaggregated by sector, in the case of the Canary Islands and Catalonia, shows that entrepreneurial opportunities vary across the regions depending on the sector of activity. This confirms Shane's (2003) view that the industrial, economic, political, and cultural context in which a person operates influences the decision to exploit entrepreneurial opportunities. Moreover, these results confirm Winters and Martins (2004) view that the development of some economic activities in remote islands-such as manufacturing-is particularly difficult. The results also support the argument that tourism is a critical area of activity in many small island states (Read, 2004); having a higher probability of success compared to other sectors (Chancellor et al., 2011).

It has been suggested that the structural characteristics of a region are responsible for regional variations in new firm formation rates (Davidsson et al., 1994). This study, however, shows that there are many similarities between new firm formation in remote islands and core regions. The three factors in new firm formation with the highest mean scores were similar between all regions: a good business idea, this is consistent with the findings from other empirical studies (e.g., Bosma et al., 2009; Orhan \& Scott, 2001); the necessary capital; and the background experience and knowledge of the business, confirming Davidsson's (1991) study. Notwithstanding these similarities, the perceptions of the effectiveness of the entrepreneurial ecosystem to provide these factors does diverge between core regions and remote islands. Additionally, the two problems encountered when creating a firm with the highest mean scores were also similar in all four regions: finding sources of finance and cost of finance, in accordance with Evans and Jovanovic's (1989) findings. Despite the confirmation of hypothesis 4, the results show that problems faced by entrepreneurs in creating a new business will be similar in remote islands and core regions. Therefore, this study contributes to the literature, especially the resource dependence theory, by showing that despite variations in the external environment, the process of new firm formation is similar in both regions. Meaning that location will not influence the type of resources needed to create a firm, since entrepreneurs in remote islands or core regions need to assemble a group of similar resources. As a result, the scarcity or abundance of critical resources in an environment will be more influential on two other distinct phases: 1) on the decision to exploit an entrepreneurial opportunity; and 2) at a later stage, in the firms' survival and growth stage. 
Implications for policy makers

The results show the important role that governments can play in the promotion and development of entrepreneurship, especially in remote islands. This study has identified practical aspects where governments can act in order to improve their entrepreneurial ecosystem. First, governments need to promote the adaptation of new technologies including use of the internet among local entrepreneurs, which will help businesses promotion and the identification of new business opportunities. Second, government should help create appropriate logistical conditions and support higher education in the information technology sector, to encourage the entrance of new entrepreneurs in this sector which is characterized by high growth businesses. Third, governments should promote interaction and cooperation between universities/research centres and firms to improve knowledge exchange and the absorptive capacity of local firms. Moreover, when attempting to strengthen local entrepreneurial ecosystems, policy makers must take into account local characteristics and the potential of the local economy-one policy will not fit all. As emphasized by Fritsch and Storey (2014, p. 950), policy "needs to reflect these differences (between rural and urban areas) and has to be tailored to local circumstances."

\section{Acknowledgements}

We thank Dr. Breda Kenny and the participants of the ECSB postdoctoral writing workshop at RENT XXVIII for their helpful comments and suggestions on an earlier draft of this paper.

\section{References}

Ács, Z., Szerb, L., \& Autio, E. (2015). The Global Entrepreneurship Index 2015. Washington: The Global Entrepreneurship and Development Institute.

Aldrich, H., \& Martinez, M. (2001). Many are called, but few are chosen: An evolutionary perspective for the study of entrepreneurship. Entrepreneurship Theory and Practice, 25(4), 41-56.

Amorós, J., Felzensztein, C., \& Gimmon, E. (2013). Entrepreneurial opportunities in peripheral versus core regions in Chile. Small Business Economics, 40(1), 11-139. https://doi.org/10.1007/s11187-011-9349-0

Anderson, A.R. (2000). Paradox in the periphery: an entrepreneurial reconstruction?. Entrepreneurship E Regional Development, 12(2), 91-109. https://doi.org/10.1080/089856200283027

Armington, C., \& Acs, Z. (2002). The determinants of regional variation in new firm formation. Regional Studies, 36(1), 33-45. https://doi.org/10.1080/00343400120099843

Armstrong J., \& Overton, T. (1977). Estimating nonresponse bias in mail survey. Journal of Marketing Research, 14(3), 396-402. https://doi.org/10.2307/3150783

Audretsch, D. \& Thurik, R. (2004). A Model of the Entrepreneurial Economy. International Journal of Entrepreneurship Education, 2(2), 143-166.

Baldacchino, G. (Ed.) (2015). Entrepreneurship in small island states and territories. New York: Routledge.

Baldacchino, G. (2006). Innovative development strategies from non-sovereign island jurisdictions? A global review of economic policy and governance practices. World Development, 34(5), 852-867. https://doi.org/10.1016/j.worlddev.2005.10.004

Baldacchino, G. (2005). Successful small-scale manufacturing from small islands: comparing firms benefiting from locally available raw material input. Journal of Small Business \& Entrepreneurship, 18(1), 21-37. https://doi.org/10.1080/08276331.2005.10593330

Baldacchino, G. (1999). Small business in small islands: a case study from Fiji. Journal of Small Business Management, 37(4), 80-84.

Baldacchino, G., \& Bertram, G. (2009). The beak of the finch: insights into the economic development of small economies. The Round Table, 98(401), 141-160. https://doi.org/10.1080/00358530902757867 
Baldacchino, G., \& Fairbairn, T. (2006). Entrepreneurship and small business development in small islands. Journal of Small Business and Entrepreneurship, 19(4), 331-340. https://doi.org/10.1080/08276331.2006.10593374

Baldacchino, L., Cassar, V., \& Caruana, A. (2008). Start-up success in a small island state: a study among entrepreneurs in Malta. Island Studies Journal, 3(1), 73-96.

Beer, S. (2004). Information flow and peripherality in remote island areas of Scotland. International Journal of Libraries and Information Services, 54(3), 148-157. https://doi.org/10.1515/LIBR.2004.148

Begley, T., Tan, W., \& Schoch, H. (2005). Politico-economic factors associated with interest in starting a business: a multi-country study. Entrepreneurship Theory \& Practice, 29(1), 35-55. https://doi.org/10.1111/j.1540-6520.2005.00068.x

Bosma, N., Acs, Z., Autio, E., Coduras, A., \& Levie, J. (2009). Global entrepreneurship monitor: 2008 executive report. Babson Park: Babson College.

Briguglio, L. (1995). Small island developing states and their economic vulnerabilities. World Development, 23(9), 1616-1632. https://doi.org/10.1016/0305-750X(95)00065-K

Bull, I., \& Winter, F. (1991). Community differences in business births and business growths. Journal of Business Venturing, 6(1), 29-43. https://doi.org/10.1016/0883-9026(91)90004-W

Burnett, K.A., \& Danson, M. (2017). Enterprise and entrepreneurship on islands and remote rural environments. International Journal of Entrepreneurship and Innovation, 18(1), 25-35. https://doi.org/10.1177/1465750316686237

Chancellor, C., Yu, C., \& Cole, D. (2011). Exploring quality of life perceptions in rural Midwestern (USA) communities: an application of the core-periphery concept in a tourism development context. International Journal of Tourism Research, 13(5), 496-507. https://doi.org/10.1002/jtr.823

Cheng, S., \& Li., H. (2011). Spatially varying relationships of new firm formation in the United States. Regional Studies, 45(6), 773-789. https://doi.org/10.1080/00343401003713415

Choi, Y., \& Phan, P. (2006). The Influences of Economic and Technology Policy on the Dynamics of New Firm Formation. Small Business Economics, 26(5), 493-503. https://doi.org/10.1007/s11187-005-5989-2

Cosh, A., \& Hughes, A. (2007). British enterprise: thriving or surviving?: SME growth, innovation and public policy 2001-2004. Cambridge: ESRC Centre for Business Research, University of Cambridge.

Cosh, A., Hughes, A., Bullock, A., \& Milner, I. (2008). Financing UK small and medium-sized enterprises: the 2007 survey. Cambridge: Centre for Business Research, University of Cambridge.

Cromie, S. (1987). Motivations of aspiring male and female entrepreneurs. Journal of Occupational Behaviour, 8(3), 251-261. https://doi.org/10.1002/job.4030080306

Danson, M., \& Burnett, K. (2014). Enterprise and entrepreneurship on islands. In: C. Henry \& G. Mcelwee (eds.), Exploring rural enterprise: new perspectives on research, policy \& practice (pp. 151-174). Bingley: Emerald.

Davidsson, P. (1991). Continued entrepreneurship: ability, need, and opportunity as determinants of small firm growth. Journal of Business Venturing, 6(6), 405-429. https://doi.org/10.1016/0883-9026(91)90028-C

Davidsson, P., Lindmark, L., \& Olofsson, C. (1994). New firm formation and regional development in Sweden. Regional Studies, 28(4), 395-410. https://doi.org/10.1080/00343409412331348356

Dubini, P. (1989). The influence of motivations and environment on business start-ups: some hints for public policies. Journal of Business Venturing, 4(1), 1-6. https://doi.org/10.1016/08839026(89)90031-1

European Union (2017). Entrepreneurship on islands and other peripheral regions. Bruxells: European Committee of Regions.

Evans, D., \& Jovanovic, B. (1989). An estimated model of entrepreneurial choice under liquidity constraints. Journal of Political Economy, 97(4), 808-827. https://doi.org/10.1086/261629 
Frederick, H., \& Monsen, E. (2009). New Zealand's perfect storm of entrepreneurship and economic development. Small Business Economics, 37(2), 187-204. https://doi.org/10.1007/s11187-009-9234-2

Fritsch, M., \& Schindele, J. (2011). The contribution of new businesses to regional employmentan empirical analysis. Economic Geography, 87(2), 153-180. https://doi.org/10.1111/j.1944$\underline{8287.2011 .01113 . x}$

Fritsch, M., \& Storey, D. (2014). Entrepreneurship in a regional context: historical roots, recent developments and future challenges. Regional Studies, 48(6), 939-954. https://doi.org/10.1080/00343404.2014.892574

García-Rodríguez, F., Gil-Soto, E., Ruiz-Rosa, I., \& Gutiérrez-Ta-o, D. (2016). Entrepreneurial process in peripheral regions: the role of motivation and culture, European Planning Studies, 25(11), 2037-2056. https://doi.org/10.1080/09654313.2016.1262827

Gartner, W. (1985). A conceptual framework for describing the phenomenon of new venture creation. Academy Management Review, 10(4), 696-706.

Goodall, B. (1987). The Penguin dictionary of human geography. Harmondsworth: Penguin.

Goodbody (2002). Entrepreneurship in Ireland. Dublin: Goodbody Economic Consultants.

Greve, A., \& Salaff, J. (2003). Social networks and entrepreneurship. Entrepreneurship Theory E Practice, 28(1), 1-22. https://doi.org/10.1111/1540-8520.00029

Grydehøj, A., Pinya, X., Cooke, G., Doratli, N., Elewa, A., Kelman, I., Pugh, J., Schick, L., \& Swaminathan, R. (2015). Returning from the horizon: introducing urban island studies. Urban Island Studies, 1, 1-19. https://doi.org/10.20958/uis.2015.1

Isenberg, D. (2010). How to start an entrepreneurial revolution. Harvard Business Review, 88(6), 40-50.

Isenberg, D. (2011). The entrepreneurship ecosystems strategy as a new paradigm for economic policy: principles for cultivating entrepreneurship. The Babson Entrepreneurship Ecosystem Project, May 11th. Retrieved from http://entrepreneurial-revolution.com/2011/05/11/theentrepreneurship-ecosystem-strategy-as-a-new-paradigm-for-economic-policy-principlesfor-cultivating-entrepreneurship/

Kaufmann, D., \& Malul, M. (2015). The dynamic brain drain of entrepreneurs in peripheral regions. European Planning Studies, 23(7), 1345-1356. https://doi.org/10.1080/09654313.2014.929639

Kirchhoff, B., Newbert, S., Hasan, I., \& Armington, C. (2007). The influence of university R\&D expenditures on new business formations and employment growth. Entrepreneurship Theory and Practice, 31(4), 543-559. https://doi.org/10.1111/j.1540-6520.2007.00187.x

Klappera, L., Laevena, L., \& Rajanc, R. (2006). Entry regulation as a barrier to entrepreneurship. Journal of Financial Economics, 82(3), 591-629. https://doi.org/10.1016/j.jfineco.2005.09.006

Levie, J., \& Autio, E. (2008). A theoretical grounding and test of the GEM model. Small Business Economics, 31(3), 235-263. https://doi.org/10.1007/s11187-008-9136-8

Lovelock, B., Lovelock, K., \& Normann, O. (2010). The big catch: negotiating the transition from commercial fisher to tourism entrepreneur in island environments. Asia Pacific Journal of Tourism Research, 15(3), 267-283. https://doi.org/10.1080/10941665.2010.503616

Martin, P. (2003). Public policies and economic geography. In B. Funck \& L. Pizzati (Eds.), European integration, regional policy, and growth (pp. 19-32). Washington: World Bank.

Mason, C., \& Brown, R. (2014). Entrepreneurial ecosystems and growth oriented entrepreneurship. Background paper presented at the workshop organised by the OECD LEED Programme and Dutch Ministry of Economic Affairs, The Hague, 7 November.

Mason, C., \& Harvey, C. (2013). Entrepreneurship: contexts, opportunities and processes. Business History, 55(1), 1-8. https://doi.org/10.1080/00076791.2012.687542

Moore, J., (1993). Predators and Prey: A new ecology of competition. Harvard Business Review, 71(3), 75-86.

OECD (2004). Fourth community innovation survey. OECD, 20 October. Retrieved from http://www.oecd.org/dataoecd/52/35/40140021.pdf 
Orhan, M., \& Scott, D. (2001). Why women enter into entrepreneurship: an explanatory model. Women in Management Review, 16(5), 232-243. https://doi.org/10.1108/09649420110395719 Quince, T., \& Whittaker, H. (2002). Entrepreneurs and their business. Cambridge: Centre for Business Research, University of Cambridge.

Read, R., (2008). Foreign direct investment in small island development states. Journal of International Development, 20(4), 502-525. https://doi.org/10.1002/jid.1477

Read, R., (2004). The implication of increasing globalization and regionalism for the economic growth of small island states. World Development, 23(2), 365-378. https://doi.org/10.1016/j.worlddev.2003.08.007

Reynolds, P., Storey, D., \& Westhead, P. (1994). Cross-national comparisons of the variation in new firm formation rates. Regional Studies, 28(4), 443-456. https://doi.org/10.1080/00343409412331348386

Romanelli, E. (1989). Environments and strategies of organisation start-up: effects on early survival. Administrative Science Quarterly, 34(3), 369-387. https://doi.org/10.2307/2393149

Shane, S. (2003). A general theory of entrepreneurship: the individual-opportunity nexus. Cheltenham: Edward Elgar. https://doi.org/10.4337/9781781007990

Shane, S. (2000). Prior knowledge and the discovery of entrepreneurial opportunities. Organization Science, 11(4), 448-469. https://doi.org/10.1287/orsc.11.4.448.14602

Shane, S., \& Venkataraman, S. (2000). The promise of entrepreneurship as a field of research. Academy of Management Review, 25(1), 217-226. https://doi.org/10.5465/AMR.2000.2791611

Spilanis, I., Kizos, T., Vaitis, M., \& Koukourouvli, N. (2013). Measuring the economic, social and environmental performance of European island regions: emerging issues for European and regional policy. European Planning Studies, 21(12), 1998-2019. https://doi.org/10.1080/09654313.2012.722970

Sufrauj, S. (2011). Islandness and remoteness as resources: evidence from the tourism performance of small remote island economies (SRIES). European Journal of Tourism, Hospitality and Recreation, 2(1), 19-41.

Sutaria, V., \& Hicks, D. (2004). New firm formation: dynamics and determinants. The Annals of Regional Science, 38(2), 241-262. https://doi.org/10.1007/s00168-004-0194-9

Tamásy, C. (2006). Determinants of regional entrepreneurship dynamics in contemporary Germany: a conceptual and empirical analysis. Regional Studies, 40(4), 365-384. https://doi.org/10.1080/00343400600612137

Welter, F. (2011). Conceptualising entrepreneurship in a transition context. International Journal of Entrepreneurship and Small Business, 3(2), 165-184.

Wennekers, S., \& Thurik, R. (1999). Linking entrepreneurship and economic growth. Small Business Economics, 13(1), 27-55. https://doi.org/10.1023/A:1008063200484

Winters, I., \& Martins, P. (2004). When comparative advantage is not enough: business costs in small remote economies. World Trade Review, 3(3), 347-383. https://doi.org/10.1017/S1474745604001922

Yusuf, A. (1995). Critical success factors for small business-perceptions of South-Pacific entrepreneurs. Journal of Small Business Management, 33(2), 68-73. 